\title{
FATIGUE EXPERIMENTS ON VERY HIGH STRENGTH STEEL BASE MATERIAL AND TRANSVERSE BUTT WELDS
}

\author{
R.J.M. Pijpers ${ }^{1,}{ }^{*}$, M.H. Kolstein ${ }^{2}$, A. Romeijn ${ }^{3}$ and F.S.K. Bijlaard ${ }^{4}$ \\ ${ }^{I} P h D$ researcher, Faculty of CiTG, TU Delft, Delft, The Netherlands; \\ Materials Innovation Institute, Delft, The Netherlands \\ *(Corresponding author: E-mail: r.j.m.pijpers@tudelft.nl) \\ ${ }^{2}$ Senior Researcher, Faculty of CiTG, TU Delft, Delft, The Netherlands \\ ${ }^{3}$ Associate Professor, Faculty of CiTG, Delft University of Technology, Delft, The Netherlands \\ ${ }^{4}$ Professor, Faculty of CiTG, TU Delft, Delft, The Netherlands
}

Received: 2 November 2007; Revised: 17 December 2007; Accepted: 24 December 2007

\begin{abstract}
Very High Strength Steels (VHSS) with nominal strengths up to 1100 MPa have been available on the market for many years. However, the use of these steels in the civil engineering industry is still uncommon, due to lack of design and fabrication knowledge and therefore limited inclusion in codes. Moreover, in a fatigue loaded VHSS structure absolute and relative stress variation will be higher compared to stresses in structures made of lower grade steels. According to current design codes the fatigue strength of welded connections mainly depends on the applied detail, plate thickness and machining condition, not on steel grade. Recently experiments on plates made of S690 and S1100, with and without transverse butt welds, have been performed in order to study the fatigue strength. Test results show that the characteristic fatigue strengths of plates with and without transverse butt weld lay well above the values according to EN 1993-1-9, mainly because of higher slope of the S-N curves. Crack initiation phase of S1100 specimens is relatively long compared to S690 specimens, while crack propagation is relatively short. An efficient application of VHSS in welded connections requires high fabrication quality and avoidance of large stress concentration in joints.
\end{abstract}

Keywords: Very High Strength Steel; High Cycle Fatigue; Transverse Butt Welds; Eurocode

\section{INTRODUCTION}

Very high strength steels (VHSS) have been made available by the steel industry for many years. However, VHSS are still rarely used by manufactures in the field of civil engineering, due to lack of adequate design and fabrication rules for these steels. Table 1 shows examples and typical application of regular structural steel, conventional high strength steel and very high strength steel.

\subsection{Background VHSS}

Potential advantages by using VHSS are evident. The use would lead to high performance products with, for example, slender and more aesthetic appearance because of reduced cross section and plate thickness. The weights and volumes of structures would be significantly reduced, resulting in novel design possibilities as well as savings in production costs of transportation and erection. Moreover smaller sizes of structures would lead to smaller weld volumes and reduced consumption of welding consumables. Finally, the ecological balance, both for production and application of the high strength steels would be improved by reduction of material, energy consumption and associated pollution.

The emphasis of the current research is laid on the high strength quenched and tempered steels with yield strengths of $690 \mathrm{MPa}$ up to $1100 \mathrm{MPa}$. These steels obtain their properties through careful control of chemical composition together with appropriate heat treatment including a rapid water quench from $900^{\circ} \mathrm{C}$ to room temperature followed by tempering, to form a fine grained martensitic microstructure [1]. 
Table 1. Typical Examples and Application of Various Steel Types

\begin{tabular}{lllll}
\hline $\begin{array}{l}\text { Strength } \\
{[\mathrm{MPa}]}\end{array}$ & Description & Other descriptions & $\begin{array}{l}\text { Typical examples } \\
\text { of grades }\end{array}$ & Typical Application \\
\hline$<300$ & $\begin{array}{l}\text { Regular } \\
\text { structural steel }\end{array}$ & Mild steel & S235 & Buildings \\
300 & $\begin{array}{l}\text { Conventional } \\
\text { high strength }\end{array}$ & $\begin{array}{l}\text { High performance } \\
\text { steel/ High tensile } \\
\text { steel }\end{array}$ & S355/S460 & $\begin{array}{l}\text { Bridges/High rise } \\
\text { buildings/Offshore } \\
\text { structures }\end{array}$ \\
700 & Very high & $\begin{array}{l}\text { Ultra high strength } \\
\text { steel/ Super high } \\
\text { strength steel }\end{array}$ & S690/S960/S1100 & Cranes/Bridges/ \\
700 & High rise buildings \\
- & strength steel & & \\
\hline 1100 & (VHSS) & & & \\
\hline
\end{tabular}

The low alloyed VHSS are still good weldable steels. VHSS material is scarce due to lack of demand for components made of these relatively new materials. Several European steel manufacturers make VHSS plate material with yield strength up to $1100 \mathrm{MPa}$ and plate thickness up to $40 \mathrm{~mm}$. Hot rolled beam cross sections are only available up to 460 yield strength. Circular hollow sections (CHS) are available in yield strength up to $890 \mathrm{MPa}$ and rectangular hollow sections (RHS) up to yield strength of $700 \mathrm{MPa}$. Table 2 summarises various steel types of plate material, CHS and RHS. Particularly in the civil engineering world design and fabrication rules need to be developed to enable a rising demand for VHSS. In the crane industry, where reduction of material directly influences the structural performance, S690 is already regarded as the standard steel grade, while plates up to strengths of S1100 are more and more daily practice.

High strength steels were initially excluded from the European steel design code Eurocode 3, by limiting the scope to specified yield strengths up to $355 \mathrm{MPa}$ only and by limiting the strength yield ratio $\mathrm{f}_{\mathrm{u}} / \mathrm{f}_{\mathrm{y}} \geq 1,2$. Annex $\mathrm{D}$ to ENV-Eurocode 3 has been the door opener for the use of conventional high strength steels (CHSS) with yield strength of $420 \mathrm{MPa}$ to $460 \mathrm{MPa}$ without needing particular technical approvals. Later on, the use of high strength steel up to S690 is allowed by the following part of Eurocode 3: Design of steel structures, Part 1.12: Additional rules for the extension of EN 1993 to steel grade S700 [2]. Crane code NPR-CEN/TS 13001-3-1 [3] is applicable to design of crane structures with high strength steel grades up to $960 \mathrm{MPa}$ yield strength.

Table 2. Available Quenched and Tempered VHSS

\begin{tabular}{llll}
\hline Manufacturer & Name & Yield strength MPa] & Type \\
\hline Dillinger Hütte GTS & DILLIMAX & $690,890,960,1100$ & Plate material \\
Thyssen Krupp & N-A-XTRA & 700,800 & \\
& XABO & $890,960,1100$ & \\
SSAB & WELDOX & $700,800,900,960$, & \\
JFE & & 1100,1300 & \\
Ilsenburger-Grobblech & HITEN & 780,980 & \\
Tenaris & MAXIL & $690,890,960,1100$ & \\
Europipe & TN 140 & 960 & Circular Hollow \\
Vallourec-Mannessmann & FGS & 690 & Sections (CHS) \\
Ruukki & Optim HS 700 & $690,770,790,890$ & \\
& MH & & Rectangular Hollow \\
& & & Sections (RHS) \\
\hline
\end{tabular}


Three governing design conditions should be fulfilled making use of VHSS in civil engineering structures the most efficient way: 1) VHSS should preferably be designed for lattice structures. Otherwise displacement might be the governing design criterion while not utilising the full material strength of VHSS; 2) In statically loaded structures attention should be paid to deformation capacity of joints, as yield to tensile ratio of VHSS may be close to 1 ; 3) In fatigue loaded structures use of joints with high stress concentrations should be avoided, whilst choosing high class details and high fabrication quality is required.

The nominal stress in a VHSS structure is usually higher than in a structure made from lower grade steels and stresses due to self weight will be lower. In absolute and relative terms this will lead to higher stress variation due to the variable load. Therefore particularly in fatigue loaded structures, a large part of all civil engineering structures, for instance bridges and offshore structures with a high number of stress cycles during their lifetime, the benefits of using VHSS are questionable if the structural design entirely depends on the fatigue strength.

In 2006 TU Delft initiated the research project 'Very High Strength Steels for Structural Applications' which will investigate possibilities for future application of these steels in the field of civil engineering. The main objective of the project is to supply the steel construction industry with information relevant for the design and fabrication of VHSS structures. The research work comprises an experimental and numerical study on the fatigue resistance of welded VHSS connections. The current paper presents the first research phase, an experimental study on the fatigue strength of plates made of S690 and S1100 with and without transverse butt welds [4,5].

\section{$1.2 \quad$ Literature Review}

Gurney [16] concluded that the higher the yield strength of base materials the more sensitive the fatigue strength of the material becomes to both the presence of notches and to the surface condition. In case of low notch values $\left(\mathrm{K}_{\mathrm{t}} \approx 1\right)$ notch sensitivity of high strength steel fatigue strength is minimized. Most literature data show a linear relation between tensile or yield strength and base material fatigue strength $[16,17]$. The mean fatigue strength is expressed as an endurable stress range at a particular number of cycles $\Delta \sigma_{\text {mean }}$. In most cases this number of cycles is taken as $2 * 10^{6}$ resulting in the $\Delta \sigma_{\text {mean } ; 2 * 106}$.

In welded VHSS structures the fatigue strength is said to be equal to lower strength steels because in VHSS micro cracks are already present due to welding, while crack propagation depends on stress range, being independent of yield strength [16,17,18]. Hübner [19] investigated the fatigue strength of S960 and gives experimental results on as-rolled base material. In Figure 2 a comparison of the $\Delta \sigma_{\text {mean;2*106 }}$ is given for plain machined specimens, millscale, as-rolled specimens and transverse butt welds, as a function of the tensile strength $\mathrm{R}_{\mathrm{m}}$. It shows, the more the geometry and surface condition degrade, the less effective a higher $R_{m}$ will be on the fatigue strength. Wellinger and Dietmann [20] describe the influence of surface roughness on fatigue strength, by relating the ultimate tensile strength of the base material to the surface roughness depth. In case of high surface roughness depth, i.e. as-rolled specimens, the relative reduction in fatigue strength increases with ultimate tensile strength of the steel. The better the surface treatment, i.e. grinding or polishing, the better the relative fatigue strength of the higher strength steels will be compared to regular steels. In practice however machining critical details is time consuming, especially for large structures.

In 2005 members of working commission 2 (Steel, Timber and Composite Structures) of the International Association of Bridge and Structural Engineering (IABSE) initiated a state-of-the-art document [6] on the use and application of High Performance Steel (HPS, $\sigma_{\mathrm{y}}<690 \mathrm{MPa}$ ). In this 
document worldwide research is included. American design experience leads to application of High Performance Steels in bridges. Canadian fatigue research showes no clear advantage of High Performance Steels over mild steel. In Japan Bridge High-Performance Steel is developed, which in combination with so called Low Transition Temperature welding may increase fatigue strength of welded joints. From European research on fatigue strength of HPS can be concluded that by improvement of the weld connection quality, for instance by reduction of surface defects or application of post-weld treatments, higher fatigue strengths can be achieved.

The German steel journal Stahlbau pays special attention to research on high strength steel in $[7,8,9]$. A research project relating to the fatigue classification of high strength steel is the project 'Efficient Lifting Equipment with Extra High Strength Steel' (LIFTHIGH), initiated by the ECSC [8]. The main research topic is the fatigue behaviour of welded high strength steel details $\left(\sigma_{\mathrm{y}}<1100\right.$ $\mathrm{MPa}$ ). Results show that in case of specimens with low stress concentration the use of high strength steel may result in higher fatigue strength compared to regular steel connections.

In [10] the use of high strength steel in crane structures is discussed. The paper shows fatigue results on base materials, welded and post weld treated joints of S355, S690 and S960. In the project 'Effizienter Stahlbau aus höherfesten Stählen unter Ermüdungsbeanspruchung' initiated by the Arbeitsgemeinschaft industrieller Forschungsvereinigungen 'Otto von Guericke' (AiF), the University of Stuttgart, Bauhaus University of Weimar and the Fachhochschule München, emphasis is laid on the use of weld improvement techniques for high strength steel connections [11]. According to [11] use of ultrasonic peening may increase the characteristic fatigue strength at 2 million cycles of welded transverse stiffners made of S460 with 40 up to $100 \%$. Ultrasonic peening proves to be even more effective at stiffners made of S690.

Compared to other welded details described in codes, the transverse butt weld detail has a relatively high fatigue classification. The design fatigue curve of EN 1993-1-9 [12] is only valid if the geometry of the welded detail is valid by the requirements for execution of steel work according to prEN 1090-2 [13], which includes hot-rolled, structural steel products up to S960. The S1100 steel is thus out of the scope of this code. According to EN 1993-1-9 [12] the fatigue design strength at 2 million cycles of a transverse butt weld detail, see Figure 1, is $90 \mathrm{MPa}$. The following criteria account for this detail class: transverse splices in plates or flats; weld run-on and run-off pieces to be used and subsequently removed; plate edges to be ground flush in the direction of stress; welded from both sides in flat position; NDT applied. For the Eurocode classification a background document is available. According to crane code CEN/TS 13001-3-1 [3] the fatigue strength of a quality $\mathrm{C}$ butt weld is $140 \mathrm{MPa}$. Backgrounds on the classification of the details in the crane code are not known to the authors.

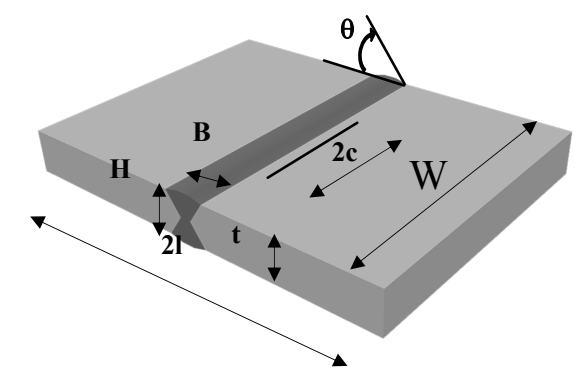

Figure 1. EN 1993-1-9 [12] Detail Category 90 
Demofonti et al [14] performed axial fatigue tests on plates with $10 \mathrm{~mm}$ transverse butt welds made of S355 up to S960. In the investigation no significant strength differences under constant amplitude loading were found in favor of use of higher steel strengths, although advantages for the S960 steel could be noticed in case of variable amplitude loading. Machining of welds, in order to achieve low notch factors is found to give an advantage for high-strength steels.

Bergers et al. [9] performed fatigue experiments on various $6-8 \mathrm{~mm}$ plate V-shaped butt weld connections made of S690, S960 and S1100. For all steel grades the characteristic fatigue strength values lay above the values of EN 1993-1-9 [12] Resulting S-N curves show a slope $m=5$ for $\mathrm{S} 1100$, which is higher than the value of $\mathrm{m}=3$ used in the design codes suitable for lower strength steels.

In Figure 2 the results of $[9,14,16,17]$ are presented as $\Delta \sigma_{\text {mean;2*106 }}$ as a function of $R_{m}$.

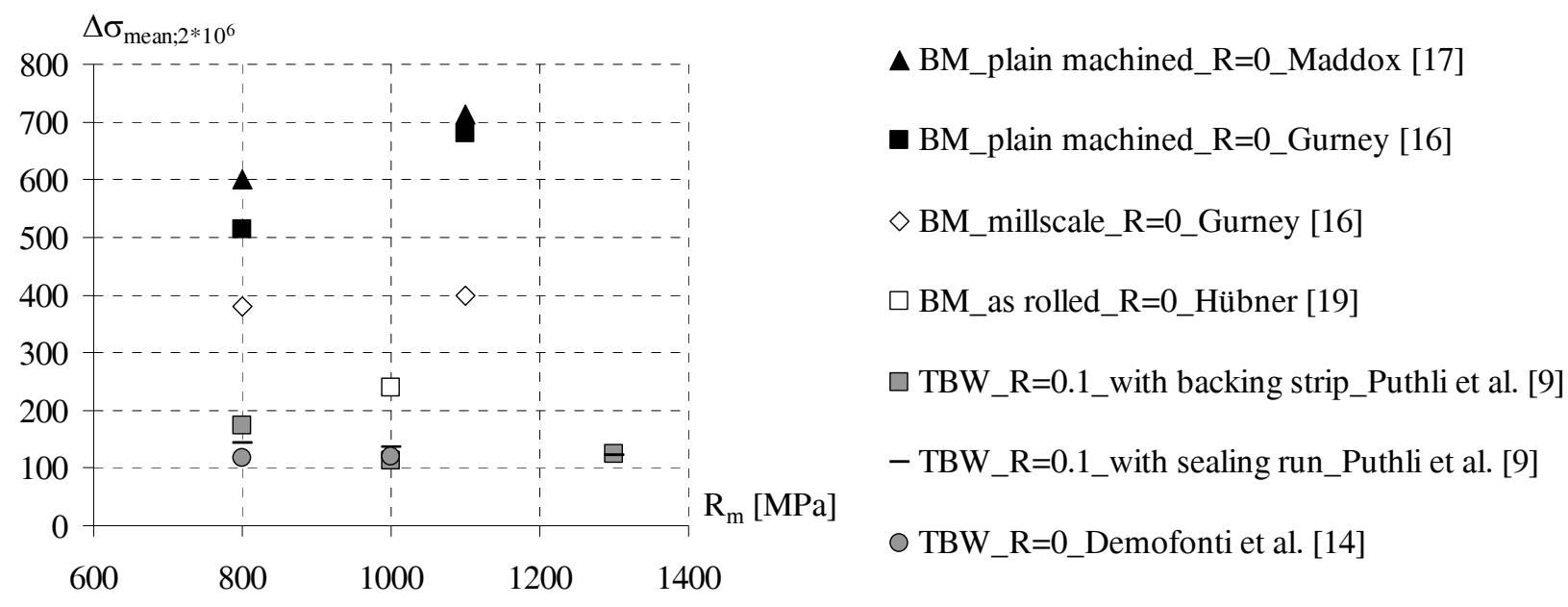

Figure 2. Fatigue Strength of Base Materials (BM) and Transverse Butt Welds (TBW)

\section{TEST SETUPAND SPECIMEN SPECIFICATIONS}

Tensile and fatigue tests have been performed at the Stevin Laboratory of the Delft University of Technology using a $600 \mathrm{kN}$ dynamic servo hydraulic test rig, see Figure 3.

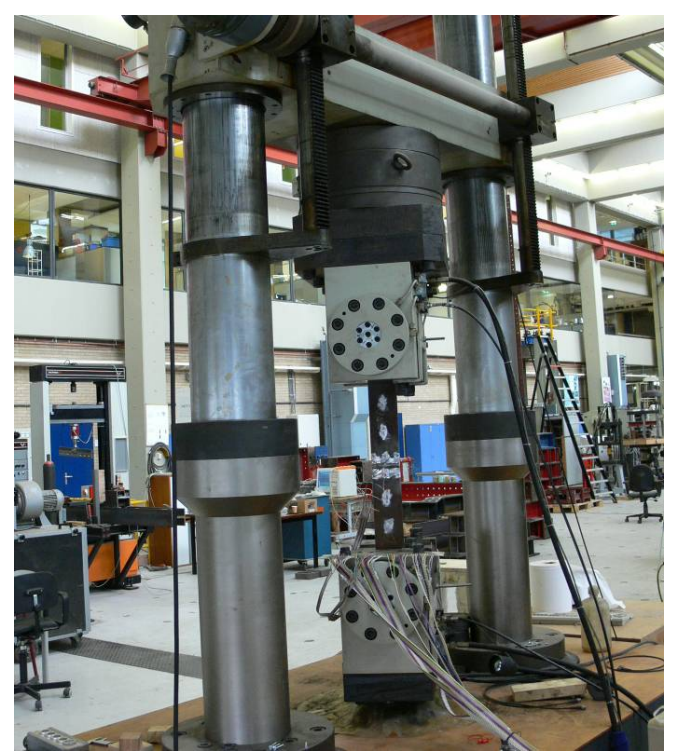

Figure 3. $600 \mathrm{kN}$ Dynamic Servo Hydraulic Test rig of the Stevin Laboratory, TU Delft 


\subsection{Plate Material Properties}

In the current research the fatigue strength of plates with and without transverse butt welds made of Naxtra M70 (S690) and Weldox S1100E (S1100) is determined. Table 3 and Table 4 give the specifications of the plate material.

Table 3. Test Material

\begin{tabular}{lll}
\hline & Steel supplier: & Grade \\
\hline Naxtra M 70 & Thyssen Krupp & S690 \\
Weldox S1100 E & SSAB & S1100 \\
\hline
\end{tabular}

Table 4. Chemical Composition

\begin{tabular}{lllllllll}
\hline Grade & $\mathrm{C}$ & $\mathrm{Si}$ & $\mathrm{Mn}$ & $\mathrm{P}$ & $\mathrm{S}$ & $\mathrm{Cr}$ & $\mathrm{Mo}$ & $\mathrm{Ni}$ \\
\hline Naxtra M 70 & 0.16 & 0.19 & 0.87 & 0.012 & 0.002 & 0.33 & 0.22 & 0.06 \\
Weldox S1100 E & 0.16 & 0.23 & 0.86 & 0.007 & 0.002 & 0.6 & 0.586 & 1.89 \\
\hline Grade & $\mathrm{V}$ & $\mathrm{Nb}$ & $\mathrm{Al}$ & $\mathrm{Ti}$ & $\mathrm{Cu}$ & $\mathrm{N}$ & $\mathrm{B}$ & $\mathrm{CE}$ \\
\hline Naxtra M 70 & & 0.026 & 0.085 & & & 0.0038 & 0.002 & 0.42 \\
Weldox S1100 E & 0.029 & 0.02 & 0.066 & 0.004 & 0.04 & 0.005 & 0.002 & 0.679 \\
\hline
\end{tabular}

For tensile tests standard test pieces have been used. Two displacement meters (POD meters) and two strain gauges (FLA-6-11) have been attached to the test specimens. Figure 4 shows the tensile test specimens and the position of the POD meters. Table 5 summarises the tensile test results compared to data from the material specifications. The S690 specimens have been plasma cut. The S1100 specimens have been tested in a plasma cut and water cut condition. Yield strength and tensile strength of the S690 specimens is consistent with the manufacturer data. The measured values of the S1100 specimens are 12\% lower than expected for the yield strength and $25 \%$ for the tensile strength when compared to the material specifications. All tensile test specimens have been cut from the plates that were welded for the fatigue specimens, after welding. Differences in measured strength and manufacturer data may be due to the fabrication influence. The Youngs modulus derived from the tensile tests is used in stress calculations in the fatigue tests using Hooks law.

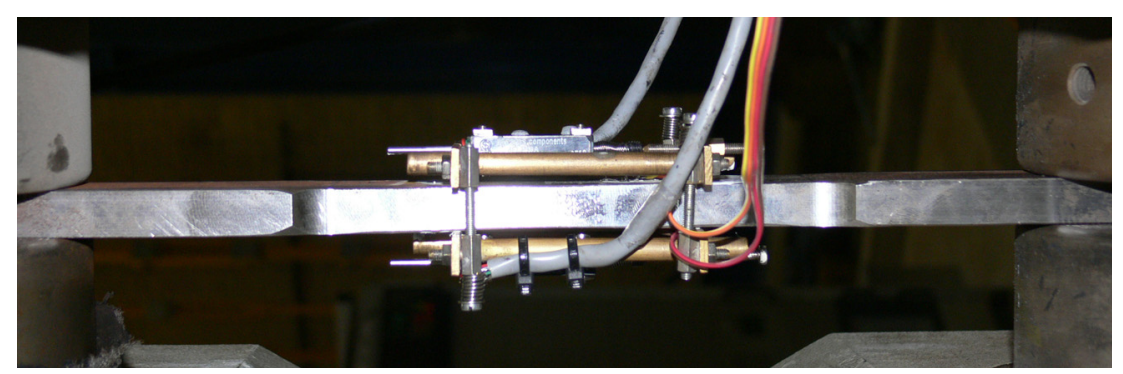

Figure 4. Tensile Test Specimen $\left(90^{\circ}\right.$ Rotated $)$

Table 5. Tensile Test Results

\begin{tabular}{llllllllll}
\hline Series & Grade & $\#$ & $\mathrm{R}_{\mathrm{eh}}$ & $\mathrm{R}_{\mathrm{m}}$ & $\mathrm{R}_{\mathrm{eh}} / \mathrm{R}_{\mathrm{m}}$ & $\mathrm{A}$ & $\mathrm{Z}$ & $\mathrm{E}$ & Preparation \\
\hline Measured & & & $\mathrm{MPa}$ & $\mathrm{MPa}$ & - & 0 & $\%$ & $\mathrm{MPa}$ & \\
\hline 1 & $\mathrm{~S} 690$ & 3 & 733 & 787 & 0.93 & 17 & 0.43 & $2.04 * 10^{5}$ & Plasma cut \\
2 & $\mathrm{~S} 1100$ & 3 & 1086 & 1135 & 0.96 & 11 & 0.57 & $2.02 * 10^{5}$ & Plasma cut \\
3 & $\mathrm{~S} 1100$ & 3 & 1117 & 1187 & 0.94 & - & 0.55 & $2.04 * 10^{5}$ & Water cut \\
\hline Data sheet & & & & & & & & & \\
\hline 1 & $\mathrm{~S} 690$ & - & 800 & 830 & 0.96 & 16 & - & & \\
2 & $\mathrm{~S} 1100$ & - & 1197 & 1432 & 0.84 & 11 & - & & \\
\hline
\end{tabular}




\subsection{Fatigue Test Procedure}

During the force controlled fatigue tests the stress ratio is kept constant at a relatively low frequency. In the crack propagation phase tests of the small base material specimens runned displacement controlled. Table 6 summarises the fatigue test conditions.

Table 6. Fatigue Test Conditions

\begin{tabular}{ll}
\hline Loading & Constant amplitude, Axial \\
Stress ratio, R & 0.1 \\
Frequency & $5.3 \mathrm{~Hz}$ \\
\hline
\end{tabular}

In general when determining the fatigue strength two phases can be distinguished: crack initiation and crack propagation. Until crack initiation, the first phase, mean strain and strain range data are stored. In case of crack growth near strain gauges this is immediately reflected in strain gauge data.

Figure 5 shows the monitoring of crack initiation by strain gauge measurements. In the graph the strain range values of two strain gauges are mentioned, strain gauge 1, near which a crack has initiated, and strain gauge 2 on the back side. Absolute stress values differ because of misalignment present in the strip specimens as a result welding, which causes additional bending stresses. The number of cycles $\mathrm{N}_{\mathrm{i}}$ at which strain gauge data start to bend of the regular scheme, clearly visible in the graph, is in the current research defined as crack initiation.

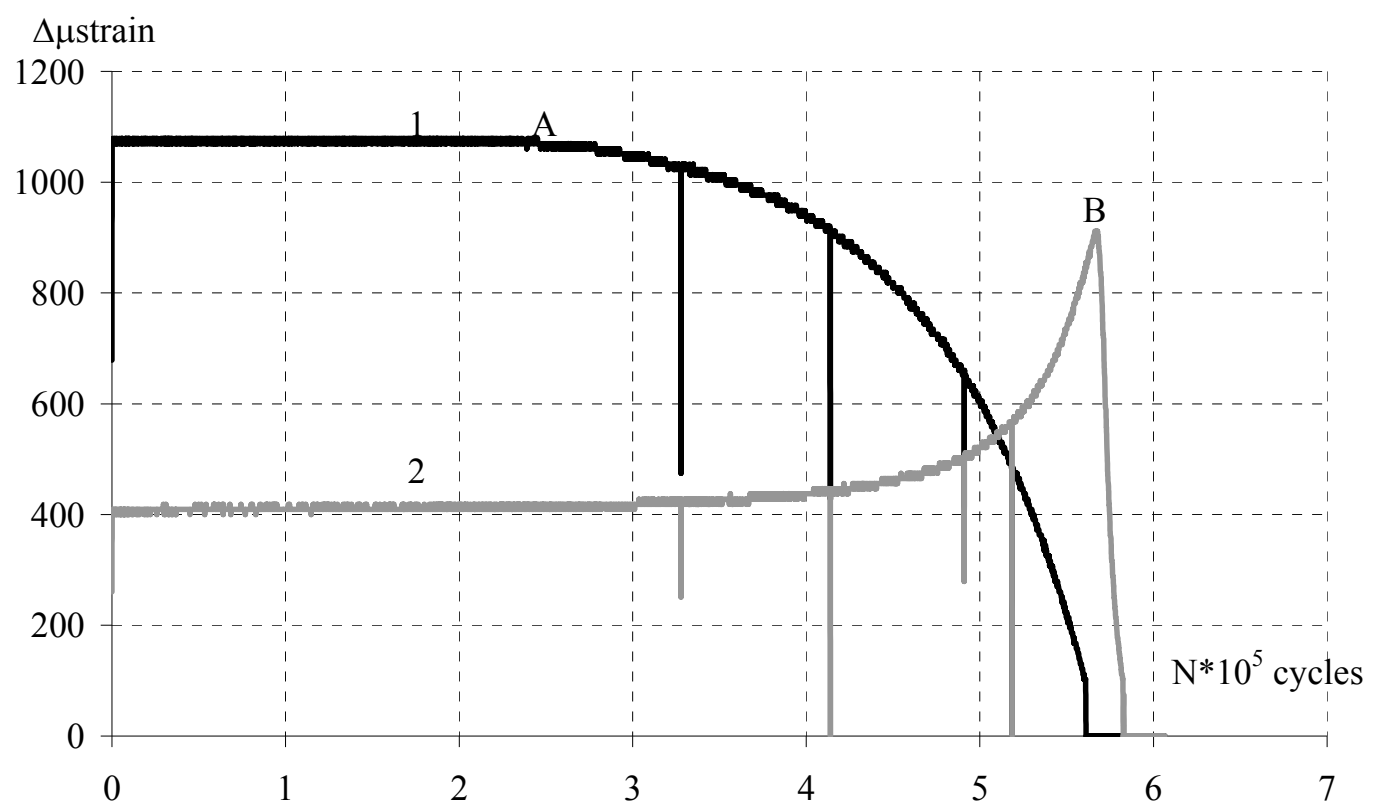

Figure 5. Strain Range Measurements of S690 Specimen FA5

An alarm system immediately shuts off the system at $10 \%$ deviation of strain ranges or strain average values, which makes it possible to indicate the locations of crack initiation. When a crack initiates the strain range values of the strain gauges near the crack decrease while the values of the strain gauge on the opposite side of the plate increase. If the crack reaches the full depth of the plate the strain range values immediately decrease, see Figure 5, point B at strain gauge 2 .

The second phase of the fatigue test procedure involves the visual inspection of crack development. A liquid (petrol) is put on the crack, which bubbles if the cracks are present. Crack propagation in plate width direction and plate thickness direction is monitored visually. Manually markings are put on the test specimens linking the numbers of stress cycles and corresponding crack lengths. For 
determination of crack length in specimen thickness direction, if not visible, the procedure of crack marking is used. During crack marking, about $10 \%$ cycles of the expected total number of cycles until failure, the upper fatigue loads are kept constant and the lower loads are increased to $90 \%$ of the upper loads. In this way boundary lines will occur, which makes it possible to determine the crack growth, when inspecting the fracture surface at the end of the experiment.

Figure 6 shows the crack marking pattern on one of the S1100 base material specimens. In the current research the crack marking method only worked on the S1100 specimens with semi-elliptical (surface) cracks. Quarter-elliptical cracks initiating from the sides of the S690 base material specimens could not be made visible by crack marking.

In the current work the number of cycles, $\mathrm{N}_{\mathrm{f}}$, until a crack reaches a length of $10 \mathrm{~mm}$, is defined as failure of the test specimen. In most cases this means through thickness cracking, followed by unstable crack growth because of the small size of the test specimens, with plate thicknesses of 10 and $12 \mathrm{~mm}$.

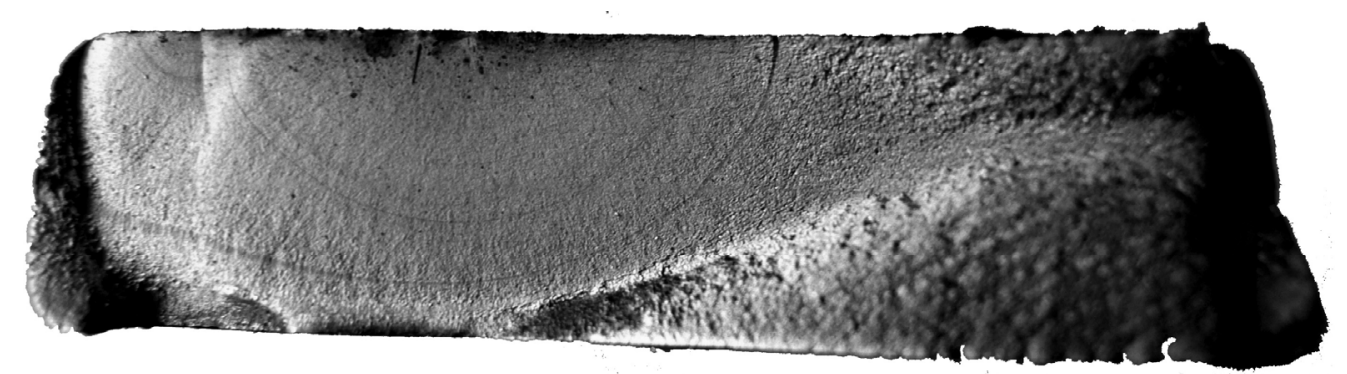

Figure 6. Cross Section of S1100 Specimen Showing Crack Marking Boundary Lines

\subsection{Base Material Fatigue Specimens}

The base material fatigue specimens have been water cut from initially welded steel plates, used for transverse butt weld specimens. After cutting, the specimens have been milled, resulting in a radius of $3 \mathrm{~mm}$ at the edges in order to prevent crack initiation from the side. At the middle the specimens have been instrumented with 4 strain gauges, see Figure 7.

Crack initiation was likely to occur at the $10 \%$ tapered cross section near these strain gauges. Extra strain gauges at $80 \mathrm{~mm}$ from the middle were used to give insight in the misalignment in the test specimens causing strains during clamping into the test rig. Table 7 gives details on the base material fatigue specimens.

Table 7. Geometry and Instrumentation of Base Material Fatigue Specimens, See Figure 7

\begin{tabular}{lll}
\hline Steel type & S690 & S1100 \\
\hline Number of test specimens & 6 & 6 \\
Number of strain gauges & 4 & 4 \\
Thickness [mm] & 12 & 10 \\
Width [mm] & 40 & 40 \\
Machining & Water cut; & Water cut; \\
& edges milled and ground & edges milled and ground \\
\hline
\end{tabular}




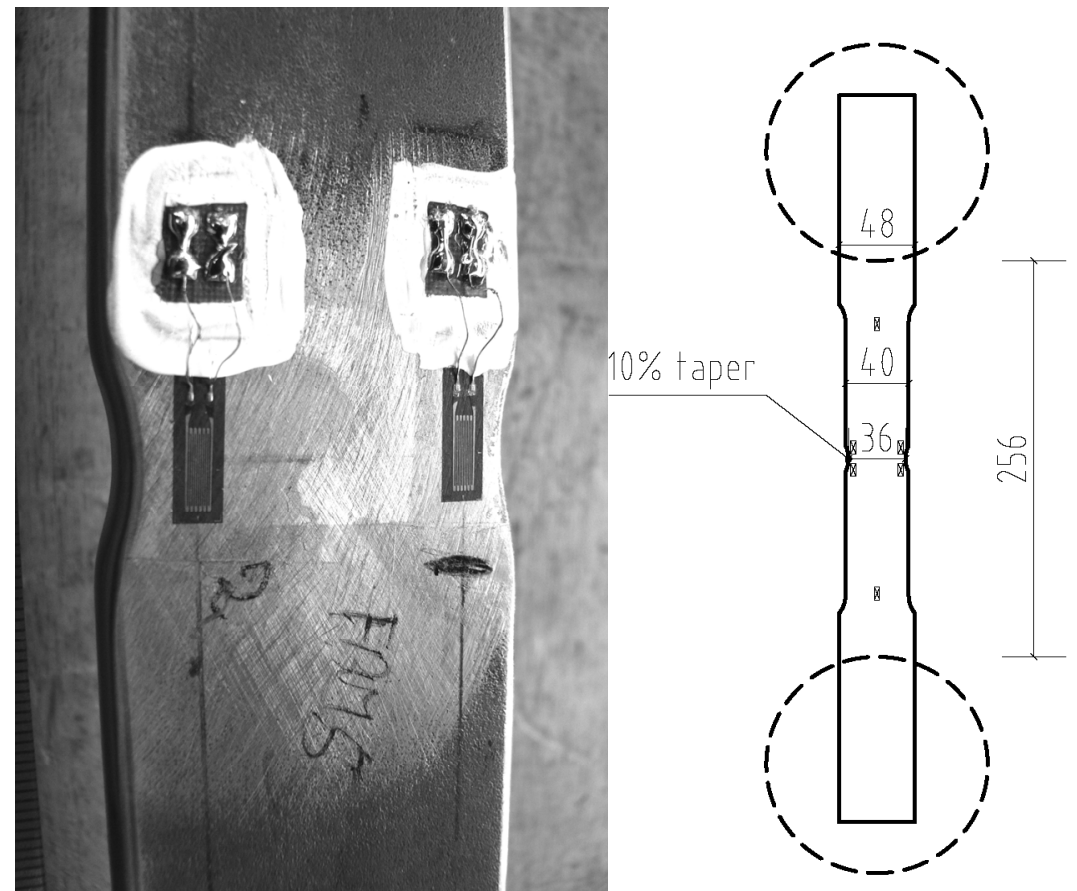

Figure 7. Base Material Fatigue Specimens

\subsection{Transverse Butt Weld Specimens}

The geometry of the transverse butt weld specimens was chosen to meet the qualifications of a class 90 butt weld detail according to EN 1993-1-9 [12] in the as-welded condition. In total thirteen test specimens have been tested; six made of S690, seven made of S1100.

Table 8 specifies the geometry of the transverse butt weld specimens and gives additional information on the weld parameters.

Table 8. Geometry and Instrumentation of Transverse Butt Weld Specimens, See Figure 1

\begin{tabular}{lll}
\hline Steel type & S690 & S1100 \\
\hline Number of test specimens & 6 & 7 \\
Number of strain gauges & 14 & 14 \\
Thickness t [mm] & 12 & 10 \\
Length 21 [mm] & 750 & 1000 \\
Width W [mm] & 120 & 100 \\
Machining & Plasma cut; edges ground & Plasma cut; edges ground \\
Weld metal & Megafill 742M & Tenacito 75 (root) \\
& & \& SH NI 2 K 140 \\
Weld process & FCAW & SMAW \\
Number of weld layers & 5 & 9 \\
Condition & Overmatched & Undermatched \\
\hline
\end{tabular}

Edges of the specimens are flame cut and ground afterwards. The X-weld shape is clearly indicated in Figure 8, which also shows Vickers Hardness test results measured at $2 \mathrm{~mm}$ below te surface. In the region of the heat affected zone of the S690 cross section a local hardness drop is found, whereas in the fusion zone of the S1100 specimens lower HV10 values are found, indicating the undermatched weld metal. 

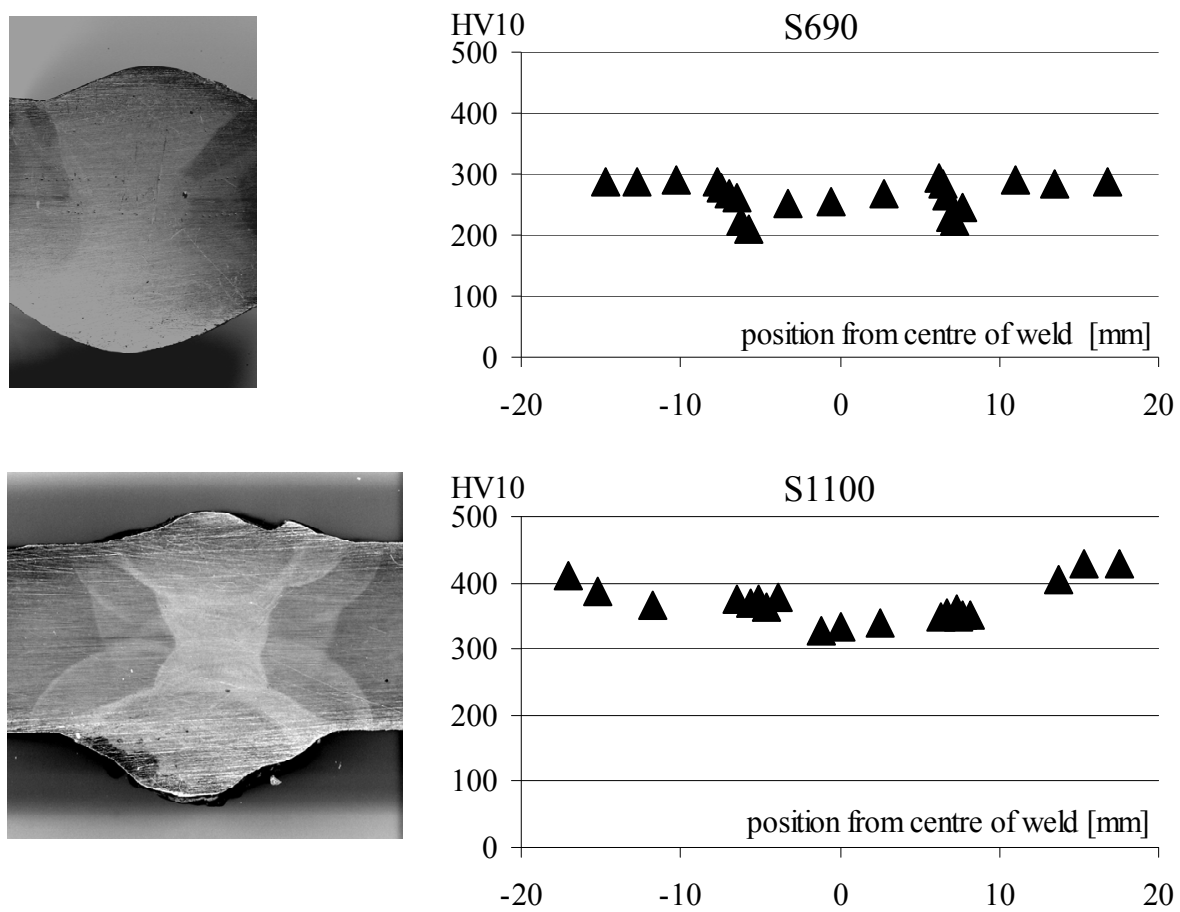

Figure 8. Cross Section of S690 and S1100 Welds and HV10 Values at $2 \mathrm{~mm}$ below the Specimen Surface

Figures 9 and 10 show the geometry and instrumentation of the S690 transverse butt weld specimens. In general the dimensions of the S690 specimens are identical to the S1100 specimens. The width of the test specimens is taken ten times the thickness of the plate material. The edges of the welded plates have been ground in order to reduce the chance of crack initiation at these edges.

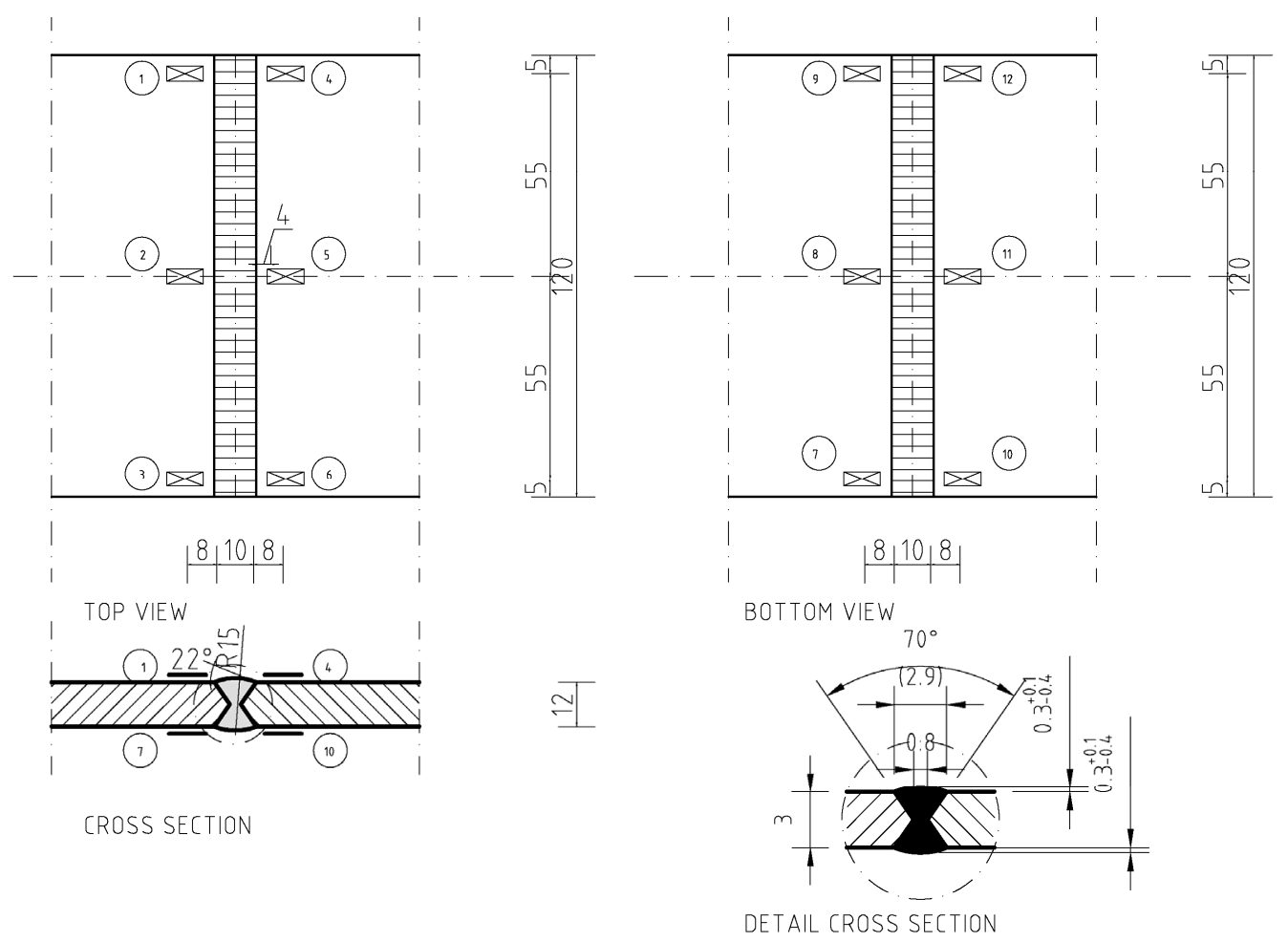

Figure 9. Instrumentation of S690 Transverse Butt Weld Fatigue Specimens 
Each specimen contains strain gauges (FLA-6-11) on both sides, at $8 \mathrm{~mm}$ from the weld toe to measure the strain distribution in plate width direction. Some of the specimens have been instrumented with special strain gauges (FXV-1-11-002LE) for the determination of stress concentration near the weld toe.

Figure 10 shows transverse butt weld specimens with extra strain gauges on the plate length for the determination of misalignment.

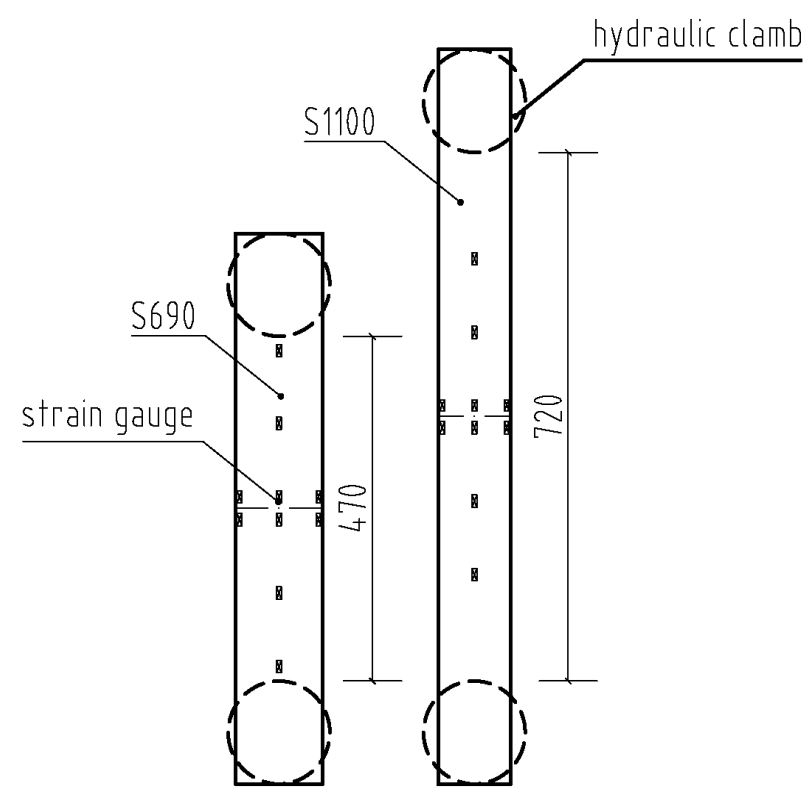

Figure 10. Transverse Butt Weld Fatigue Specimens

In order to check the strain distribution in the plate length direction the specimens have been statically loaded up to stress levels of $30 \%$ of the yield strength. Figure 11 shows the longitudinal stress pattern for various applied forces at six strain gauge positions. The measured values are the average tensile stresses at the top of the specimens near the weld, at $100 \mathrm{~mm}$ and $200 \mathrm{~mm}$ from the weld and at the middle of the plate.

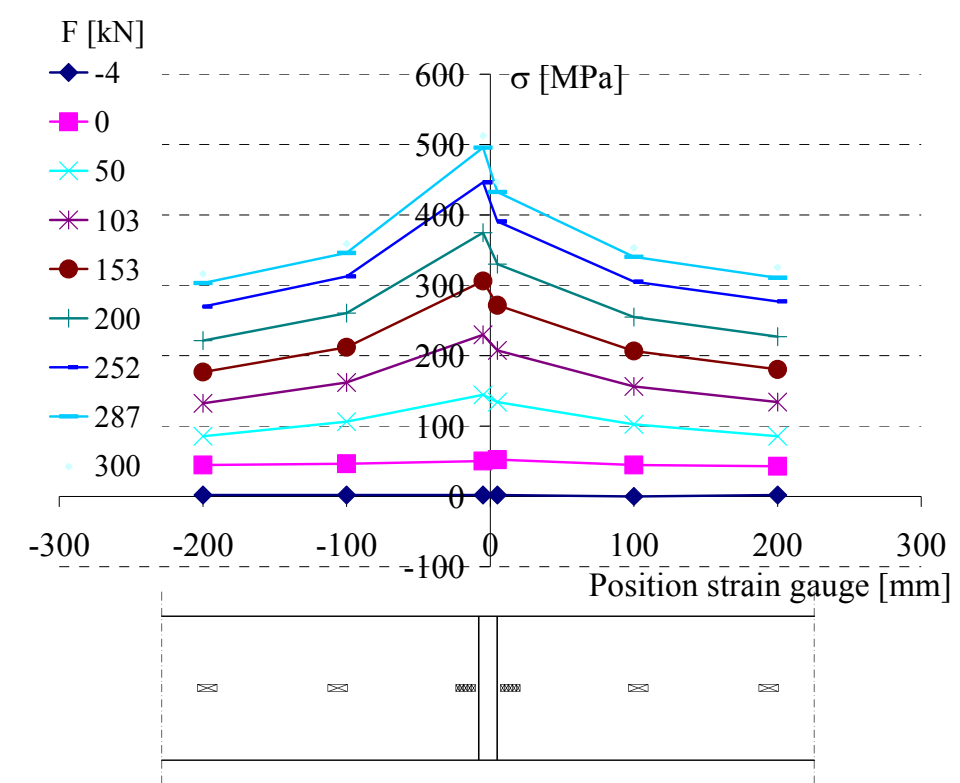

Figure 11. Longitudinal Stress Pattern 
Non-linear behaviour of the stresses in longitudinal direction can be explained as follows. Due to shrinkage after welding the test specimens are all bent along the axis of the weld. This causes a non-linear behaviour of the stresses as a result of increasing the tensile load when the specimens are clamped in the test rig. At high stress levels the test rig straightens the test specimens.

Hobbacher [21] gives calculation rules, Eq. 1, Eq. 2 and Eq. 3, for a stress magnification factor, $\mathrm{k}_{\mathrm{m}}$, in case of misalignment in transverse butt welded plates. Figure 13 illustrates the geometrical parameters used in these formulas.

$k_{m}=1+\frac{3 y}{t} \cdot \frac{\tanh \left(\frac{\beta}{2}\right)}{\left(\frac{\beta}{2}\right)}$

in which $\beta=\frac{2 l}{t} \cdot \sqrt{\frac{3 \cdot \sigma_{m}}{E}}$

$\sigma=k_{m} * \sigma_{m}$

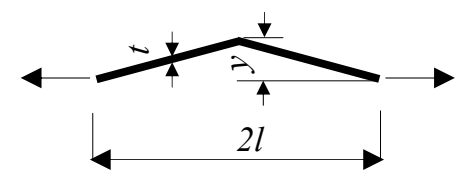

Figure 12. Misalignment Parameters After Hobbacher [21]

The formula also shows the influence of the nominal stress level $\sigma_{\mathrm{m}}$ on the misalignment factor. At high stress levels the effect of secondary bending stresses is large compared to low stress levels. Measured stress values at $4 \mathrm{~mm}$ from the weld toe are compared to calculated stress values $\sigma$ according to Eq. 3. The stress measurements of both the S690 and the S1100 welds are in good correspondence with the calculated results.

Table 9 summarizes local geometry details of all fatigue tested specimens. The table gives minimum values of weld width $B$, measured and calculated values of the excess of weld metal $\mathrm{h}$ (see Figure 13) and the misalignment parameter y (see Figure 12). prEN 1090-2 [13] limits the excess of weld metal at transverse butt welds quality C according to EN-ISO 5817 [22], see Eq. 4 and Figure 13.

$$
h<1+0.15^{*} B[\mathrm{~mm}]
$$

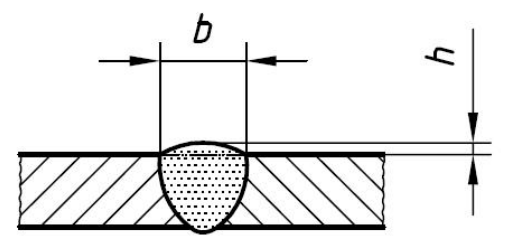

Figure 13. Weld Metal Excess According to EN-ISO 5817 [22]

In test specimen FA2 made of S690, for which code prEN 1090-2 [13] is valid, and in all specimens made of S1100 the weld metal excess value has been exceeded. The yield and tensile strength of the weld material are lower than the plate material strength of S1100. Therefore the undermatched S1100 welds have been made thicker than allowed according to prEN 1090-2 [13]. 
Table 9. Local Geometry Fatigue Specimens, See Figures 1, 12 and 13

\begin{tabular}{clllll}
\hline & specimen & $\mathrm{B}_{\text {min }}$ & $\mathrm{h}$ & $\mathrm{h}$ & $\mathrm{y}$ \\
\hline & & & measured & \multicolumn{2}{l}{ calculated } \\
\hline S690 & & $\mathrm{mm}$ & $\mathrm{mm}$ & $\mathrm{mm}$ & $\mathrm{mm}$ \\
\hline FA1 & 10 & 2.5 & 2.5 & 4 \\
& FA2 & 10.3 & $2.9^{*}$ & 2.5 & - \\
FA3 & 8 & 1.2 & 2.2 & 5 \\
FA4 & 9 & 1.3 & 2.4 & 2.5 \\
FA5 & 7 & 1.3 & 2.1 & 7 \\
FA9 & 9 & 1.5 & 2.4 & 4.5 \\
\hline S1100**FB1 & 10 & $3.0^{*}$ & 2.5 & 6 \\
FB2 & 11 & $2.8^{*}$ & 2.7 & 3.7 \\
FB3 & 9 & $3.5^{*}$ & 2.4 & 7 \\
FB4 & 13 & $3.0^{*}$ & 3.0 & 7 \\
FB5 & 12 & $2.5^{*}$ & 2.8 & 8 \\
FB6 & 11.5 & $2.7^{*}$ & 2.7 & 8 \\
FB9 & 11 & $3.3^{*}$ & 2.7 & 7.5 \\
\hline
\end{tabular}

* value does not satisfy EN-ISO 5817 [22]

**material out of scope of prEN 1090 [13]

\section{FATIGUE TEST RESULTS}

The current chapter presents crack growth data and S-N curves as a result from fatigue tests.

\subsection{Fatigue Tests Base Materials}

At all S690 specimens cracks initiated from the taper location, where the average stress level was $10 \%$ higher than in the cross section out of the tapered part. In the S1100 specimens, 10\% tapered as well, cracks initiated at the cross section outside the taper location. Crack growth in plate thickness direction of both S690 and S1100 base material specimens is illustrated by Figure 14.

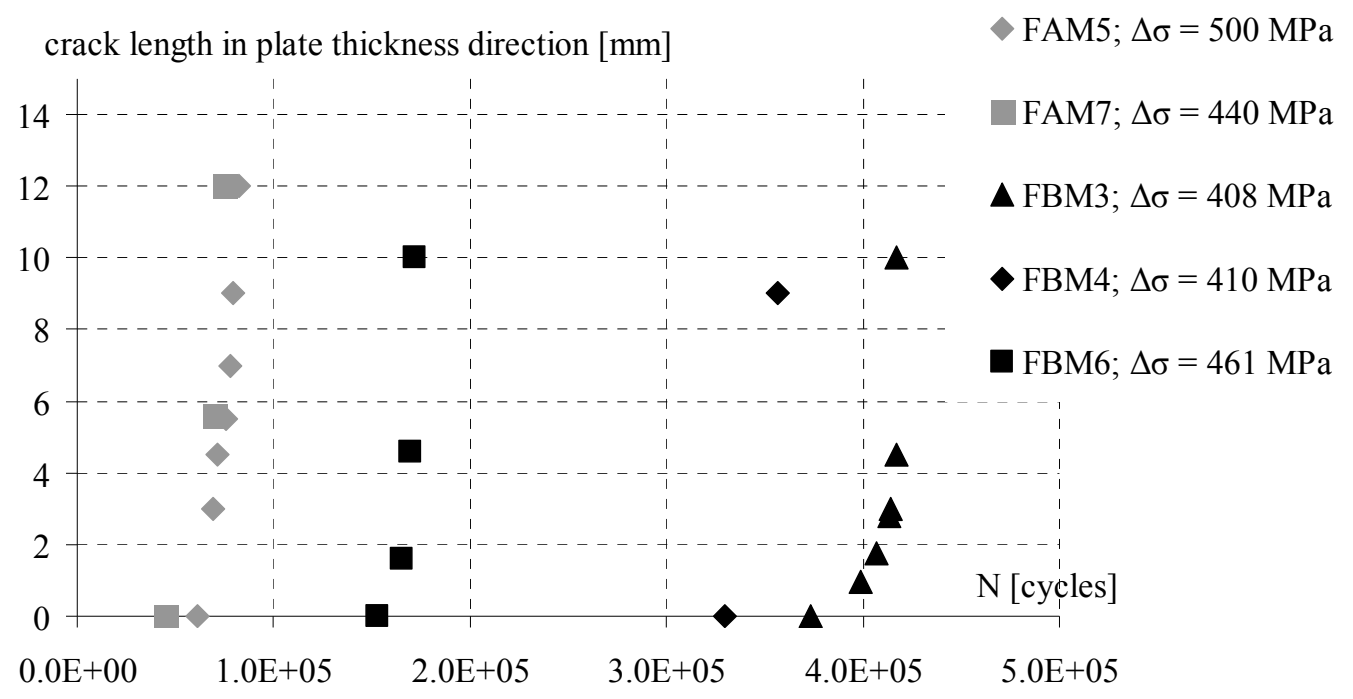

Figure 14. Crack Growth of Base Material Specimens 
Most of the cracks in the S690 specimens initiated form the edges at the tapered cross section. At the S1100 specimens cracks initiated at the surface, outside of the tapered cross section. In only few S690 specimens crack propagation could be monitored properly, because the crack marking method gave no visible crack boundary lines of the fracture surface. Next to that the $\mathrm{N}_{\mathrm{f}}$ is very close to the $\mathrm{N}_{\mathrm{i}}$ at various stress levels, which indicates rapid crack growth after crack initiation.

According to Hobbacher [21] the characteristic stress range values at 2 million cycles, $\Delta \sigma_{c}$, are calculated for a $95 \%$ survival probability on a two-sided confidence level of $75 \%$ of the mean, based on Eq. 5. The number of test pieces is small; therefore the value of $\mathrm{k}$ is set to 3, which is a safe approximation. In Table 10 the fatigue results of the base material specimens are listed.

$$
\log N_{c}=(a-k * S t d v)+b^{*} \log \Delta \sigma_{c}
$$

Figure 15 shows the results of the base material fatigue tests presented as a S-N curve, based on nominal stress ranges versus number of cycles until failure. As can be seen at Figure 15 the S690 characteristic fatigue values are well above class 160 of EN 1993-1-9 [12] and class 225 of the NPR-CEN/TS 13001-3-1 [3] in the high cycle fatigue region, mainly because of higher slope values.

Table 10. Fatigue results base material specimens

\begin{tabular}{|c|c|c|c|c|}
\hline & Specimen & $\Delta \sigma$ & $\mathrm{N}_{\mathrm{i}}\left(* 10^{5}\right)$ & $\mathrm{N}_{\mathrm{f}}\left(* 10^{5}\right)$ \\
\hline & & $\mathrm{MPa}$ & cycles & cycles \\
\hline \multirow{6}{*}{ S690 } & FAM2 & 270 & $-*$ & $44 *$ \\
\hline & FAM3 & 511 & - & 1.5 \\
\hline & FAM4 & 414 & 55.8 & 56.3 \\
\hline & FAM5 & 500 & 0.6 & 0.8 \\
\hline & FAM6 & 450 & 2.9 & 3.3 \\
\hline & FAM7 & 440 & 0.5 & 0.8 \\
\hline \multirow[t]{6}{*}{ S1100 } & FBM1 & 587 & - & 0.7 \\
\hline & FBM2 & 459 & - & 2.0 \\
\hline & FBM3 & 408 & 3.7 & 4.2 \\
\hline & FBM4 & 410 & 3.3 & 3.6 \\
\hline & FBM5 & 378 & $-*$ & $25.0^{*}$ \\
\hline & FBM6 & 461 & 1.5 & 1.7 \\
\hline \multicolumn{5}{|c|}{$*$ No crack initiation } \\
\hline & S690 & & S1100 & \\
\hline$\Delta \sigma_{\text {mean } ; 2 * 10^{6}}$ & 399 & & 339 & \\
\hline$\Delta \sigma_{\mathrm{c}}$ & 391 & & 317 & \\
\hline $\mathrm{m}$ & 13.3 & & 6.8 & \\
\hline \#specimens & 5 & & 6 & \\
\hline
\end{tabular}

The scatter in the S690 and S1100 results is relatively small. The calculated $\Delta \sigma_{c}$ level of the S690 specimens is $391 \mathrm{MPa}$, which is much higher than the $\mathrm{S} 1100$ value of $317 \mathrm{MPa}$, while initially a higher value for the S1100 specimens was expected. Surface roughness influence could be the cause for the different crack initiation locations.

The surface at the tapered cross section has been ground for application of strain gauges. In the locations outside of the tapered cross section, except from the edges, the as-rolled condition applies for the surface condition, having a higher surface roughness. Apparently the S1100 material is more sensitive to this higher surface roughness, causing earlier crack growth at locations with higher surface roughness at a relatively lower stress level. 


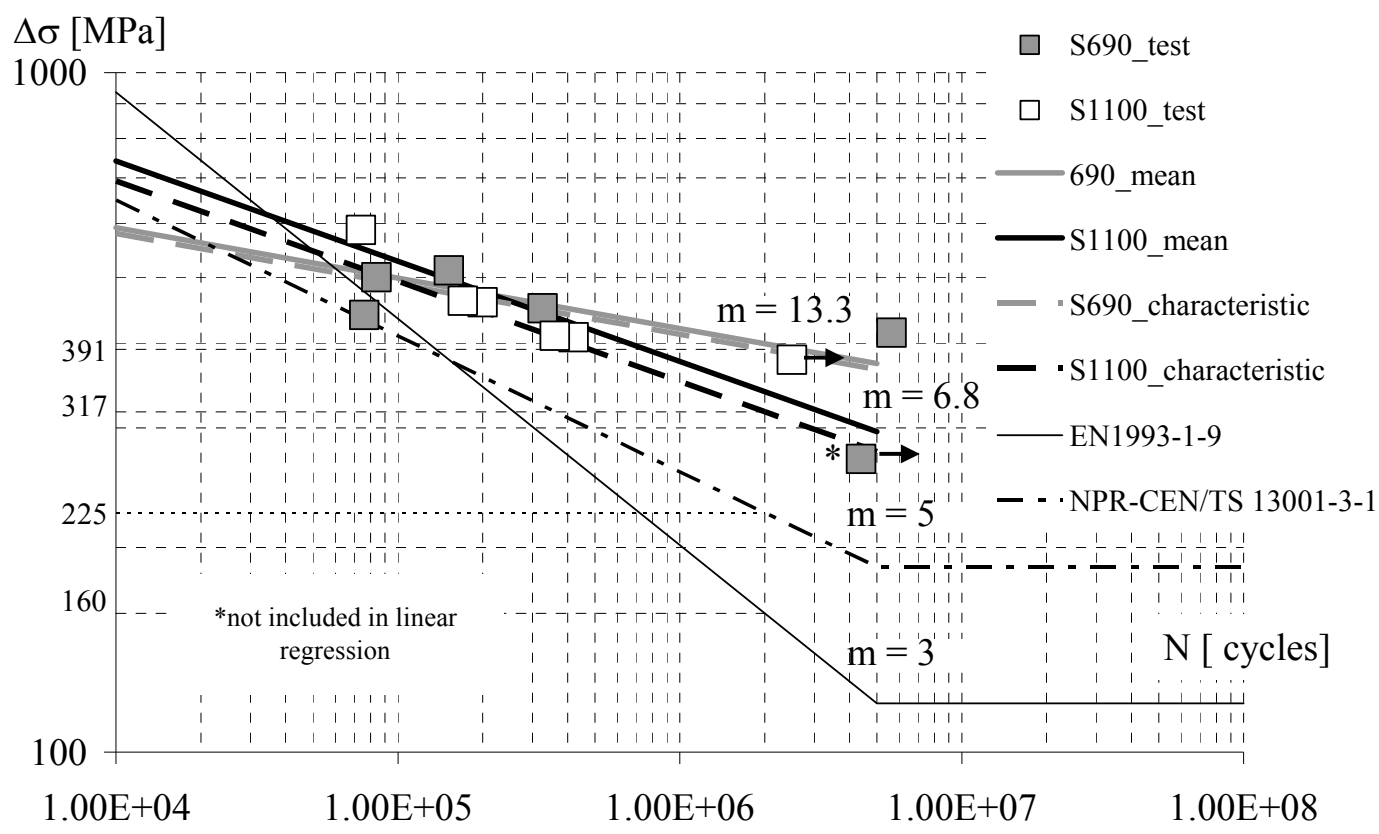

Figure 15. S-N Curve of Base Material Specimens

\subsection{Fatigue Tests Transverse Butt Welds}

Figure 16 shows the crack propagation in the plate thickness direction of S690 and S1100 specimens, tested at various stress levels. Except from the FA4 specimen of S690 in all specimens cracks have initiated from the plate edges near the weld toe. In the FA4 specimen cracks occurred at multiple locations, also at the surface near the weld toe.

In two specimens no cracks have occurred at high number of cycles; in one of the S690 specimens at a stress range of $110 \mathrm{MPa}$ and in one of the $\mathrm{S} 1100$ specimens at a stress range of $200 \mathrm{MPa}$. At similar stress range level a comparison of crack growth behaviour between S690 and S1100 specimens can be made, for instance when looking at specimens FA5 (S690) and FB5 (S1100), loaded up to a comparable stress range level. The crack initiation phase of FB5 compared to FA5 is relatively long, while the crack propagation is relatively short, see Figure 16.

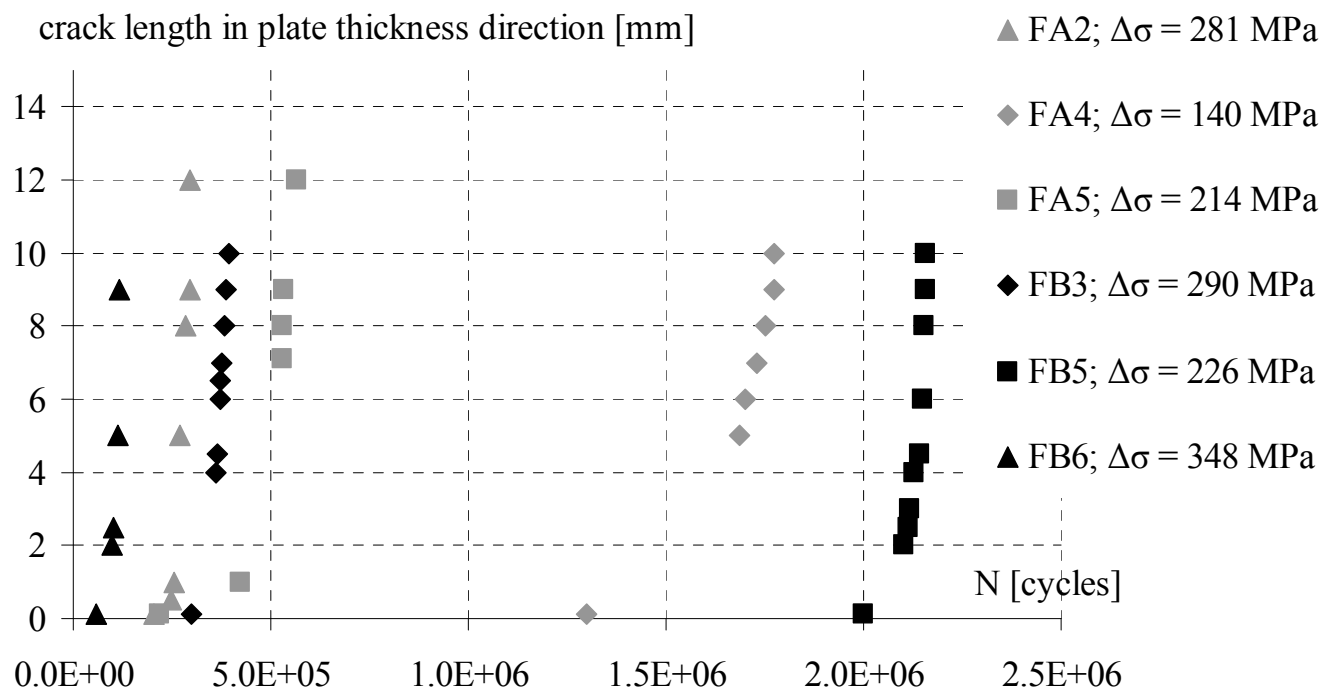

Figure 16. Crack Growth of Transverse Butt Weld Specimens

As for the base materials, the fatigue data of the transverse butt welds is evaluated according to Hobbacher [21]. 
Based on Eq. 5, the characteristic stress range values at 2 million cycles, $\Delta \sigma_{c}$, are calculated for a $95 \%$ survival probability on a two-sided confidence level of $75 \%$ of the mean. The value of the $\mathrm{k}$ is set to 3, which again is a safe approximation because of the relatively low amount of test specimens. In Table 11 the fatigue results of the transverse butt weld specimens are listed.

Table 11. Fatigue Results Transverse Butt Weld Specimens

\begin{tabular}{|c|c|c|c|c|}
\hline & Specimen & $\Delta \sigma$ & $\mathrm{N}_{\mathrm{i}}\left(* 10^{5}\right)$ & $\mathrm{N}_{\mathrm{f}}\left(* 10^{5}\right)$ \\
\hline & & $\mathrm{MPa}$ & cycles & cycles \\
\hline \multirow[t]{6}{*}{ S690 } & FA1 & 110 & $-*$ & $47.0^{*}$ \\
\hline & FA2 & 281 & 2.0 & 3.0 \\
\hline & FA3 & 275 & 2.4 & 3.4 \\
\hline & FA4 & 140 & 13.0 & 18.0 \\
\hline & FA5 & 214 & 2.2 & 6.0 \\
\hline & FA9 & 132 & 13.0 & 24.1 \\
\hline \multirow[t]{7}{*}{ S1100 } & FB1 & 200 & $-*$ & $80.0^{*}$ \\
\hline & FB2 & 512 & 0.1 & 0.2 \\
\hline & FB3 & 290 & 3.0 & 4.1 \\
\hline & FB4 & 268 & 1.5 & 3.0 \\
\hline & FB5 & 226 & 19.0 & 21.4 \\
\hline & FB6 & 348 & 0.6 & 1.2 \\
\hline & FB9 & 246 & 0.8 & 2.1 \\
\hline \multicolumn{5}{|c|}{ *No crack initiation } \\
\hline & S690 & & S1100 & \\
\hline$\Delta \sigma_{\text {mean } ; 2 * 10^{6}}$ & 143 & & 212 & \\
\hline$\Delta \sigma_{\mathrm{c}}$ & 92.5 & & 180 & \\
\hline $\mathrm{m}$ & 2.8 & & 5.7 & \\
\hline \#specimens & 6 & & 7 & \\
\hline
\end{tabular}

Figure 17 shows the results of the transverse butt weld fatigue tests, presented in an S-N curve. The calculated $\Delta \sigma_{\mathrm{c}}$ of the S690 specimens is $92 \mathrm{MPa}$, which is in good correspondence with a high quality butt weld of regular steel, equal to class 90 of EN 1993-1-9 [12] but is lower than $\Delta \sigma_{c}$ according to class 140 of NPR CEN/TS 13001-3-1 [3]. The slope value $\mathrm{m}$ of the S-N line of 2.8 is lower than the slope value of 3 according to both codes.

The results of the S1100 material show a fatigue behaviour different from the S690 material. The slope $\mathrm{m}$ of 5.7 is higher than the value of 2.8 of the S690 specimens, which is consistent with research results of Puthli et al. [9]. The calculated $\Delta \sigma_{\mathrm{c}}$ level of the $\mathrm{S} 1100$ specimens is $180 \mathrm{MPa}$, which is also much higher than the S690 value. 


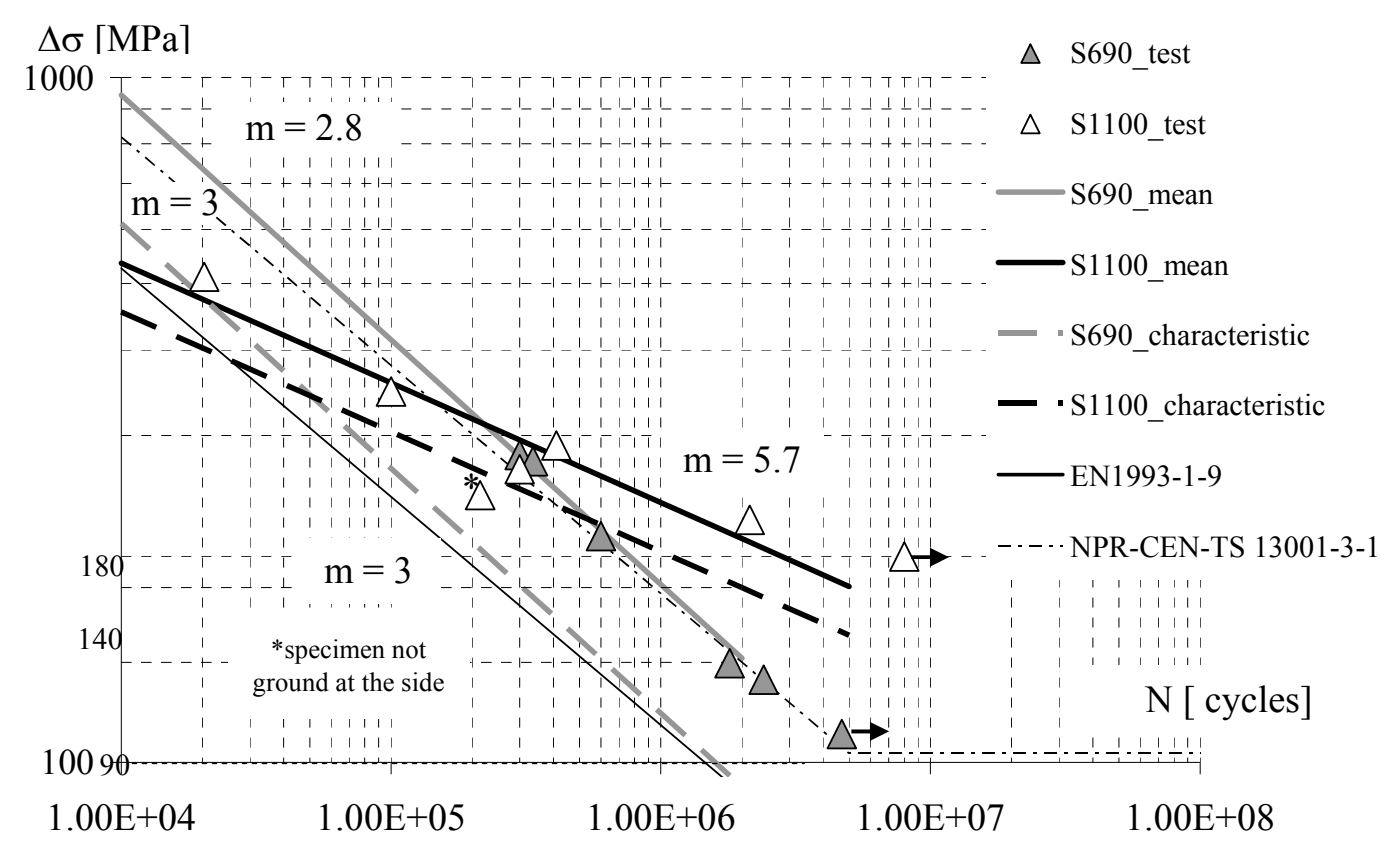

Figure 17. S-N Curve of Transverse Butt Weld Specimens

\section{CONCLUSIONS}

When applying S1100 in civil engineering structures it should be noticed that high fabrication quality is essential for obtaining the expected yield and tensile strengths. Especially S1100 material is very sensitive to thermal influence and surface condition.

The current research gives experimental results on the fatigue strength of plates with and without transverse butt welds. As EN 1993-1-12 [2] makes EN 1993-1-9 [12] applicable to steels up to yield strength of $700 \mathrm{MPa}$, the experimental data of the S690 specimens could be compared to this code. The characteristic fatigue strength of the S690 specimens lays well above the presented value of EN 1993-1-9 [12], mainly because of higher slope value in the S-N curve. The tests on as-rolled VHSS specimens show a relatively higher fatigue strength of S690 specimens in relation to the S1100 specimens. Cracks of S1100 specimens initiated outside the 10\% tapered cross section, whereas the cracks of the S690 specimens initiated from the edges at the tapered cross section. Therefore the lower fatigue strength of the S1100 specimens is probably due to the surface roughness influence.

From experimental data of VHSS transverse butt weld specimens can be concluded that specimens made of S1100 have a higher characteristic fatigue strength than specimens made of S690, mainly because of a higher slope in the S-N curve. The characteristic fatigue strength of the S690 specimens was very close to the value of EN1993-1-9 [12] class 90.

Crack growth is monitored visually. Because of the low amount of crack propagation data of the base material specimens a comparison of crack growth between S690 and S1100 could not be made. The crack growth data of transverse butt weld specimens show, while the crack initiation phase is very long, crack propagation of the S1100 specimens is relatively short compared to the S690 specimens. 
For future design recommendations making effective use of VHSS in fatigue loaded structures it will be necessary to optimise the geometrical conditions of structural details, using joints with a relatively high detail classification and low stress concentration. Optimal conditions could be reached by applying cast steel joints in combination with VHSS, resulting in joints with low stress concentration, while shifting the weld out of the most severe stress location.

\section{ACKNOWLEDGEMENT}

This research was carried out under the project number MC8.06265 in the framework of the Research Program of the Materials innovation institute M2i (www.m2i.nl), the former Netherlands Institute for Metals Research. The authors would like to thank the personnel of the Stevin Laboratory of the Delft University of Technology for the technical support and the firm Huisman Itrec for the welding of the test specimens.

\section{REFERENCES}

[1] Schröter, F., "Höherfeste Stähle für den Stahlbau - Auswahl und Anwendung", Bauingenieur, 2003, Vol. 9, pp. 426-432.

[2] prEN 1993-1-12, "Design of Steel Structures - General - Part 1.12 : Additional Rules for the Extension of EN 1993 up to Steel Grades S700", European Committee for Standardization, 2004.

[3] NPR-CEN/TS 13001-3-1, "Cranes - General design - Part 3.1: Limit States and Proof of Competence of Steel Structures", European Committee for Standardization, 2004.

[4] Pijpers, R.J.M., Kolstein, M.H., Romeijn, A. and Bijlaard, F.S.K., "The Fatigue Strength of Butt Welds Made of S690 and S1100", Proceedings of the $3^{\text {rd }}$ International Conference on Steel and Composite Structures, Manchester, 2007, pp. 901-907.

[5] Pijpers, R.J.M., Kolstein, M.H., Romeijn, A. and Bijlaard, F.S.K., "The Fatigue Strength of Base Material and Butt Welds Made of S690 and S1100", Proceedings of the $5^{\text {th }}$ International Conference on Advances in Steel Structures, Singapore, 2007, Vol. III, pp. 603-608.

[6] Günther, H.P. and Kuhlmann, U., "Use and Application of High Performance Steels for Steel Structures", IABSE Structural Engineering Documents 8, 2005.

[7] Herion, S. and Müller, C., "Untersuchung Kranspezifischer Kerbdetails", Stahlbau, 2000, Vol. 4, No. 69, pp. 251-267.

[8] Puthli, R., Herion, S. and Bergers, J., "Untersuchungen zum Ermüdungsverhalten von hochfesten Stählen im Rahmen von LIFTHIGH", Stahlbau, 2006, Vol. 11, No. 75, pp. 916-924.

[9] Bergers, J., Herion, S., Höhler, S., Müller, C. and Stötzel, J., "Beurteilung des Ermüdungsverhaltens von Krankonstruktionen bei Einsatz hoch- und ultrahochfester Stähle", Stahlbau, 2006, Vol. 11, No. 75, pp. 897-915.

[10] Hamme, U, J. Hauser, A. Kern and Schriever, U., "Einsatz hochfester Baustähle im Mobilkranbau", 2000.

[11] Kuhlmann, U., Dürr, A. and Günther, H.P., "Verbesserung der Ermüdungsfestigkeit höherfester Baustähle durch Anwendung der UIT-Nachbehandlung”, Stahlbau, 2006, Vol. 11, No. 75, pp. 930-938.

[12] EN 1993-1-9, "Design of steel structures - General - Part 1.9: Fatigue Strength of Steel Structures", European Committee for Standardization, 2005. 
[13] prEN 1090-2, "Execution of Steel Structures and Aluminium Structures - Part 2: Technical Requirements for the Execution of Steel Structures", European Committee for Standardization, 2005.

[14] Demofonti, G., Riscuifuli, S., Sonsino, C.M., Kaufmann, H., Sedlacek, G., Müller, C., Hanus, F. and Wegmann, H.G., "High-strength Steels in Welded State for Lightweight Constructions under High and Variable Stress Peaks", Final Report EUR 19989, Luxembourg, 2001.

[16] Gurney, T.R., "Fatigue of Welded Structures", UK, 1979.

[17] Maddox, S.J., "Fatigue Strength of Welded Structures", Abington Publishing, 1991

[18] Radaj, D., "Design and Analysis of Fatigue Resistant Welded Structures", Abington Publishing, 1990.

[19] Hübner, P., "Schwingfestigkeit der hochfesten schweissbaren Baustähle StE 885 und StE 960", Technischen Universität Bergakademie Freiberg, Germany, 1996.

[20] Wellinger, K. and Dietmann, H., "Festigkeitsberechnung", Alfred Körner Verlag, Stuttgart, 1976.

[21] Hobbacher, A., "Recommendations for Fatigue Design of Welded Joints and Components", IIW document XIII-1965-03 / XV-1127-03, 2004.

[22] EN-ISO 5817, Welding - Fusion-welded Joints in Steel, Nickel, Titanium and Their Alloys (Beam Welding Excluded) - Quality Levels for Imperfections, ISO Copyright Office, Switzerland, 2003. 